\title{
LIKA - AN EXAMPLE OF SOCIO-GEOGRAPHIC CHANGE IN HIGHLAND CROATIA
}

\author{
Dane Pejnović, * \\ LIKA - PRIMER SOCIALNO GEOGRAFSKE TRANSFORMACIJE GORSKE HRVATSKE \\ Izvadak \\ UDK 911.3(497.5 Lika) \\ Lika je dio gorske Hrvatske i najveća problemska regija u okviru nacionalnog prostora. U \\ radu su razmotreni uzroci i dinamika iseljavanja te najvažniji aspekti socijalno-geografske \\ transformacije povezano s tim.
}

Ključne riječi: Lika, Hrvatska, socijalna geografija, transformacija

LIKA - AN EXAMPLE OF SOCIO-GEOGRAPHIC CHANGE IN HIGHLAND CROATIA

\section{Abstract}

Lika is a part of highland Croatia and the greatest problem region within the framework of the national territory. The causes and dynamics of emigration and the most important ensuing aspects of socio-geographic transformation are considered in this work.

Key Words: Lika, Croatia, social geography, transformation

\footnotetext{
* Dr., univ. prof., Geography Department, Faculty of Science, University of Zagreb, Maruličev $\operatorname{trg} 19,10000$ Zagreb, Croatia
} 


\section{INTRODUCTION}

The geographic term Lika refers to the spacious karst depression in the southeastern part of highland Croatia. Lika's spatial isolation between the Velebit, Kapela and Plješivica mountain chains, macro-relief structure with the characteristics of a morphologically disjointed morpho-structure, predominantly environmental features of a continental-mountain climatic area and unique cultural landscape formed after secondary colonization from the end of the seventeenth and beginning of the eighteenth centuries within the framework of a western Dinaric cultural tradition clearly mark it as a well-defined physiognomic region within highland Croatia.

With a surface area of $5,283 \mathrm{~km}^{2}$, it encompasses 9.3 percent of the total surface of the Republic of Croatia. In addition to this spatial extent and its share of the overall national territory, the wider supra-regional value of the region is determined by its position as a contact and connection between the continental inland (the northwestern part of highland Croatia and the peri-Pannonian Kordun region) and the coastal Adriatic front (the Croatian Littoral and Dalmatia). Such a mediating function predisposed by its position between the two principal naturally and geographically differing yet economically complementary population and developmental zones of Croatia additionally stresses the intersecting transit/geographic location of Lika between the three leading Croatian developmental poles: Zagreb, Rijeka and Split (Fig. 1)

The overall importance of the region is also enhanced by significant autochthonous economic potential (forests, agricultural lands), exceptional concentrations of natural heritage sites (Plitvice Lakes National Park, Velebit Nature Park, the Cerovac caves, etc.) as a basis for tourism development

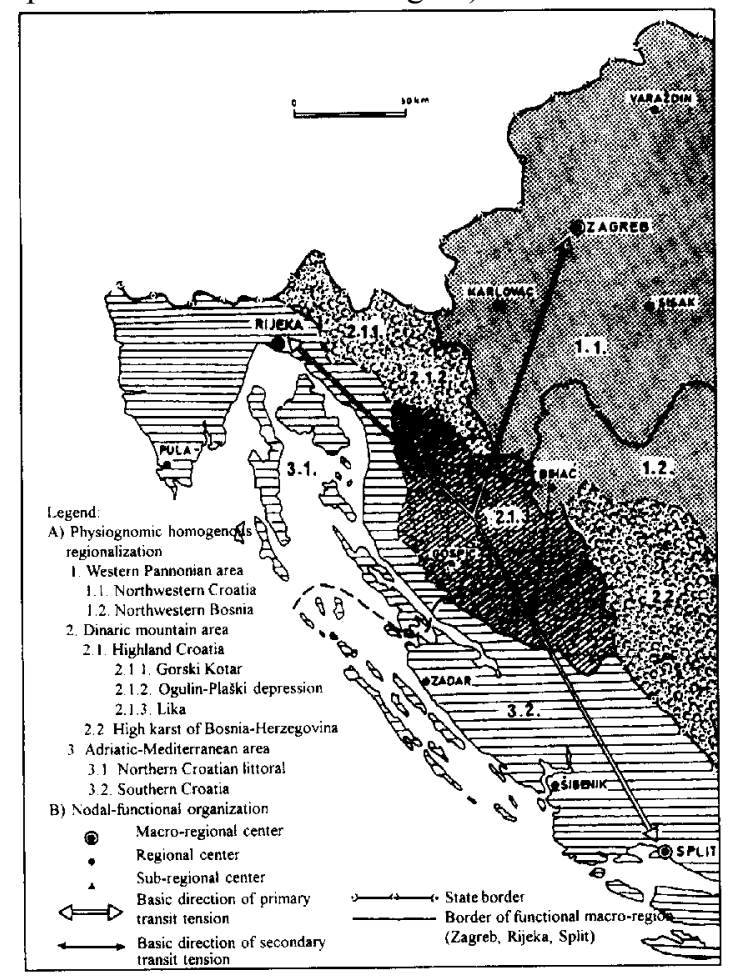

Fig. 1. Regional and geographic position of Lika 
and its geomorphologically predisposed function as the environmental heart of Croatia. The long-lasting current function of this highland-montane region as the primary geostrategic heart of Croatia also has to be added to the above factors.

Nonetheless, in contrast to these factors of importance within the national territory, with regard to its contemporary socio-economic developmental characteristics, Lika is the greatest problem region of Croatia. This is true both from the aspect of spatial extent and the depth of the crisis features of contemporary demographic, economic, social and spatial development. The fundamental cause of this situation is long-term and occasionally very intense emigration, as well as the direct and indirect demographic losses during the war from 1991 to 1995, which had far-reaching negative consequences in the population structure and the dynamics and composition of the population of this region.

The objective of this work is to study the causes, intensity and consequences of depopulation and the ensuing negative spatial processes in the region, which in this sense is a representative example of the socio-geographic transformation of the highland regions of Croatia as a whole.

\section{DISCUSSION}

\section{Causes of Emigration}

Emigration of the population is one of the fundamental features of the sociogeographic development of Lika, which makes it one of the most marked emigration regions in the Republic of Croatia. The basic impulse factor of emigration from the region is its constant lagging in the socio-economic development of the country as a whole. Within the framework of the cause and effect factors which permanently contribute to the slower development of this region, three groups of causes stand out in particular: 1. an unfavorable natural and geographic basis, 2. the uniqueness of its historical and geographic development, and 3. the peripheral socio-geographic position.

During the period when traditional agriculture predominated, from the beginning of the eighteenth century until the Second World War, the most significant emigration causal factor was the domination of the karst relief and the related shortage of arable land. Under conditions of high natural growth (as a result of demographic transition), this was reflected in the growing discrepancy between the excessive population and the region's production potential, which manifested itself in excessive agricultural overpopulation, meaning that it had the characteristics of a passive region. 
These two characteristics--agrarian overpopulation and food shortages--which cause its passiveness, were fundamental features of the region until the 1970s. Thus in 1931, it was estimated that the Lika County of the time had an excess 66,557 inhabitants in relation to the food-producing potential of the region, which was almost 40 percent of its total population. This problem was particularly pressing in the most barren karst terrain of southern Lika, where the estimated surplus reached as much as 46.9 percent of the total population (Bićanić, 1940:26-29). Despite the absolute and relative large demographic losses during World War II and the postwar period, as well as the longterm emigration of the population, agrarian overpopulation characterized this karst area until the end of the 1960s. Therefore, in 1960 a surplus of 11,235 agricultural workers were calculated in relation to the necessary labor force on individual farms, which accounted for approximately one fifth of the total number of active agricultural workers (Figenwald, 1964:74, 96).

When speaking of natural and geographic conditions as a factor for the lag in economic development, then the relatively unfavorable climate should be added to the karst nature of the terrain. Namely, due to the Mediterranean precipitation regime (maximum outside of the vegetation period, washed out pedological cover, summertime droughts) and extreme temperatures (frosts, a short vegetation period, summertime droughts), the climate is also a significant limiting factor for agricultural production, which together with a smaller amount of products causes a narrower assortment of crop cultures.

On the other hand, the unfavorable historical and geographic development of Lika during the eighteenth and a larger part of the nineteenth centuries as a military border region, or a frontier, influenced the long-term domination of its military-strategic function, with the corresponding reflection in the spatial development and sociopsychological characteristics of the population. This caused a former military-frontier region to miss a developmental step in relation to other Croatian regions which had already entered the industrial era. During the period of industrialization after World War II, the differences among them grew at an alarming rate (Pejnović, 1997:60).

This is confirmed by data from the middle of the 1960 s according to which three of the five Lika municipalities of the time fell into the category of insufficiently developed regions of Croatia. Since the beginning of the 1970s all of the municipalities were in this category of problem regions (Narodne novine, 18/1996, $33 / 1997$ ), while at the beginning of the 1980s this was the only Croatian region in which the index of general development was under two thirds $(60.2 \%)$ of the republic average (Baletić, 1985:193).

The fundamental causes of this lag in Lika during this most dynamic period of socioeconomic development in Croatia, which were reflected in the corresponding processes of spatial polarization and differentiation, were its peripheral sociogeographic position in relation to the republic's leading centers on the one hand, and 
the lack of its own regional center to anchor the entire region on the other. Although it was nominally, with regard to the moderate (directive) gravitation, organized as a part of the Rijeka functional macro-region, because of the distance from its living space and spatial isolation, the spatial reality of Lika permanently determined the intermixture of the gravitational influence of Zagreb, Rijeka and Zadar. It is from this aspect that the region maintained the characteristics of a poorly-developed rural area all up until the most recent times, with increasingly marked features of a problem region in the Republic of Croatia.

\section{Spatial and Temporal Pulsation of Emigration}

Although temporary and sporadic emigration from the region was present during the entire military-frontier period, with an intensification during the short period of change from Austrian to French sovereignty from 1807 to 1811 , it was only at the beginning of the 1870 s that a large wave of emigration occurred. This large emigration outflow was the result of the combined factors of the large European agrarian crisis which had considerable effects in Croatia from 1873 to 1895 (Bićanić, 1974-1975:50) and the abolishment of the restrictive military-frontier legislation in 1871, which gave the region's inhabitants greater freedom of movement. Under the conditions of a socio-economic crisis of the time and agrarian overpopulation, this emigration had the character of an essentially necessary mechanical outflow of an overly numerous population. During the 1870 s, this emigration was primarily directed toward the flatland regions of Croatia and Slavonia. The intensity of this emigration is illustrated by data from 1890 that 6,594 persons from Lika were recorded in Požega County alone, as well as a saying of the time according to which "it seems as though there are more people from Lika in eastern Croatia than in Lika itself" (Horvat, 1942:33-45). From the beginning of the 1880s, emigrants from Lika also began to increasingly participate in overseas emigration. In the last two decades of the eighteenth century, less than 9,000 residents of the Lika-Krbava County of the time emigrated to overseas countries in the last two decades of the eighteenth century. The largest wave of overseas emigration from the region came during the first decade of this century, or rather, the period all up until World War I. At this point, it assumed the characteristics of true flight (Lakatoš, 1914:3). In this manner, during the 19001910 period over 15,000 Lika residents emigrated to the United States alone (V. Mikačić, 1978:81). Between the two world wars, emigration from Lika to other countries greatly lessened, although it continued until World War II, but with changing intensity and directions (because of the restrictive immigration policies of the United States; from the middle of the 1920s emigration to Latin America and Western Europe predominated). Emigration to the country's flatlands, primarily Slavonia, once more acquired greater significance during this period.

Constant emigration, demographic losses during World War II and postwar emigration caused a reduction of over one fourth of the population of the region in the 
1931-1948 intercensal period (by 47,719 inhabitants, or a rate of $-27 \%$ ). Although the data on wartime and postwar victims cannot be considered final, because they are continually being supplemented with the results of new partial research, the lower limit of Lika's demographic losses during World War II, bearing in mind the aforementioned reservations, can be taken as a number of 22,162 of persons who were killed or died (Žerjavić, 1989: 154, 155). This can only be a number used for orientation, which confirms the thesis that demographic losses from 1941 to 1945 under the conditions of a dichotomic national composition and ideological and political confrontation form the principal feature in the depopulation of the region from 1931 to 1948. A similar relativity is valid for data on postwar emigration in the flatland regions of the country. Only within the framework of organized colonization in 1945 and 1946, 2,593 families with 13,779 inhabitants from Lika alone migrated (Maticka, 1990: 70, 73). The sporadic emigration of an unspecified number of individual emigrants has to be added to this number, as well as those who moved to urban areas during the period under observation.

In contrast to emigration before World War II, the postwar emigration proceeded under the conditions of accelerated de-agrarianization and stagnation of the region in the even more complex socio-economic development of Croatia. The fundamental driving factor of emigration continued to be agrarian overpopulation (until the beginning of the 1970s), while the attracting factor under conditions of accelerated socio-economic development in the country was urban-based industrialization. Since the developmental stagnation of the region did not create the conditions for a gathering of the population in the leading town of Lika, Gospić, the primary destinations of emigration from mid-century were developed urban centers in the country, above all Zagreb and Rijeka.

The considerable surge of emigration from the middle of the 1960s was caused by the legalization of so-called temporary work abroad. Namely, the relative material betterment and changes of value systems associated with work abroad was, in a majority of cases, the basis for permanent changes in places of residence with the goal of "securing better opportunities for our children." The importance of this phenomenon is indicated by the fact that there were 6,424 Lika inhabitants with temporary residence abroad in 1971, which is 6.1 percent of the population of Lika. Up to 1991, their number increased to 7,991, or 9.6 percent of the region's population. Data on the growth of employment abroad in Lika's active population (from 10 percent in 1981 to a significant 14.5 percent of the active population in 1991) can also be taken as an indirect indicator of Lika's stagnation in the socio-economic development of the country. From the socio-geographic standpoint, a specifically interesting aspect is that residents of western Lika (central Lika and Gacka) primarily went abroad to work. Up to 1991, these areas were predominantly inhabited by Croats with 64.1 percent of the population (18.9 percent of the active population working abroad in 1991), while the population of eastern Lika (Krbava, southern Lika and 
Ličko Pounje), where Serbs predominated by an 83 percent share, there was a lower instance of working abroad (7.7 percent of the active population working abroad in 1991).

Certainly the best synthetic indicator of the developmental stagnation of Lika in the period of the quickest socio-economic transformation of Croatia since the beginning of the 1960s is the fact that in the 1961-1991 intercensal period almost a third of the population from the beginning of the 1960s emigrated from the region (Table 1).

Table 1: Dynamics of Emigration from Lika and its Regions, 1961-1991.

\begin{tabular}{|l|c|c|c|c|c|c|c|c|}
\hline Region & \multicolumn{8}{|c|}{ Migration Balance } \\
\hline & $1961-1971$ & \multicolumn{1}{|c|}{$1971-1981$} & $1981-1991$ & $1961-1991$ \\
\hline & Abs. & $\%$ & Abs. & $\%$ & Abs. & $\%$ & Abs. & $\%$ \\
\hline Central Lika* & -5186 & -12.9 & -6070 & -16.2 & -753 & -2.4 & -12012 & -29.9 \\
\hline Gacka & -5068 & -15.1 & -4283 & -12.6 & -790 & -3.0 & -10141 & -30.3 \\
\hline Krbava & -3497 & -20.3 & -2224 & -15.1 & -551 & -4.5 & -6272 & -36.3 \\
\hline Southern Lika & -3661 & -20.2 & -2857 & -19.2 & -972 & -8.2 & -7490 & -42.6 \\
\hline Ličko Pounje & -1889 & -17.6 & -1294 & -13.5 & -167 & -2.0 & -3350 & -31.2 \\
\hline LIKA & $\mathbf{- 1 9 3 0 4}$ & $\mathbf{- 1 6 . 2}$ & $\mathbf{- 1 6 7 2 8}$ & $\mathbf{- 1 5 . 6}$ & $\mathbf{- 3 2 3 3}$ & $\mathbf{- 3 . 6}$ & $\mathbf{- 3 9 2 6 5}$ & $\mathbf{- 3 2 . 9}$ \\
\hline
\end{tabular}

Source: Pejnović, 1991: 73

* The data deal with the territory of the Gospic municipality from 1991, which in addition to central Lika (the modern city of Gospić and the Perušić municipality) encompassed the central portion of the Velebit littoral (Karlobag municipality).

The differing features of geo-factors were reflected in differentiated emigration rates, with a range between less than 30 percent emigration in central Lika to over 40 percent in the southern part of the region. The greatest spatial movement was attained during the 1960s, and then during the 1970s, while the advanced aging process during the 1980s "left no one who could emigrate." Such a mechanical outflow of the population could be characterized as a population hemorrhaging, with numerous negative implications to the structure of the population and to the demographic, economic, social and spatial development of the region.

\section{The Recent Depopulation of Lika}

Under the primary influence of demographic transition, Lika achieved its maximum population level at the turn of the century (in 1900 it had 189,479 inhabitants, i.e. a general relative population density of 35.6 inhabitants $/ \mathrm{km}^{2}$ ). After this, a continual, and occasionally very intense, depopulation process began. The greatest absolute and relative reduction of the population occurred under the influence of wartime losses and emigration during the 1940s, and the aforementioned rural exodus from the beginning of the 1960s (Table 2). 
Table 2: Changes in the Population of Lika and its Regions, 1961-1991.

\begin{tabular}{|l|c|c|c|c|c|c|c|c|}
\hline Region & \multicolumn{2}{|c|}{$1961-1971$} & \multicolumn{2}{c|}{$1971-1981$} & \multicolumn{2}{c|}{$1981-1991$} & \multicolumn{2}{c|}{$1961-1991$} \\
\hline & Abs. & $\%$ & Abs. & $\%$ & Abs. & $\%$ & Abs. & $\%$ \\
\hline Central Lika* & -2790 & -6.9 & -6120 & -16.4 & -1971 & -6.3 & -10882 & -25.0 \\
\hline Gacka & -2900 & -8.7 & -4077 & -13.4 & -1714 & -6.5 & -8691 & -26.0 \\
\hline Krbava & -2629 & -16.2 & -2376 & -16.2 & -969 & -7.9 & -5974 & -34.6 \\
\hline Southern Lika & -2767 & -15.7 & -2956 & -19.9 & -1429 & -12.0 & -7152 & -40.7 \\
\hline Ličko Pounje & -1118 & -10.4 & -1162 & -12.1 & -399 & -4.7 & -2679 & -25.0 \\
\hline LIKA & $\mathbf{- 1 2 2 0 4}$ & $\mathbf{- 1 0 . 2}$ & $\mathbf{- 1 6 7 2 8}$ & $\mathbf{- 1 5 . 6}$ & $\mathbf{- 4 7 5 5}$ & $\mathbf{- 5 . 3}$ & $\mathbf{- 3 3 6 5 0}$ & $\mathbf{- 2 8 . 2}$ \\
\hline
\end{tabular}

Source: Censuses for the years listed.

* The data deal with the territory of the Gospić municipality from 1991, which in addition to central Lika (the modern city of Gospić and the Perušić municipality) encompassed the central portion of the Velebit littoral (Karlobag municipality).

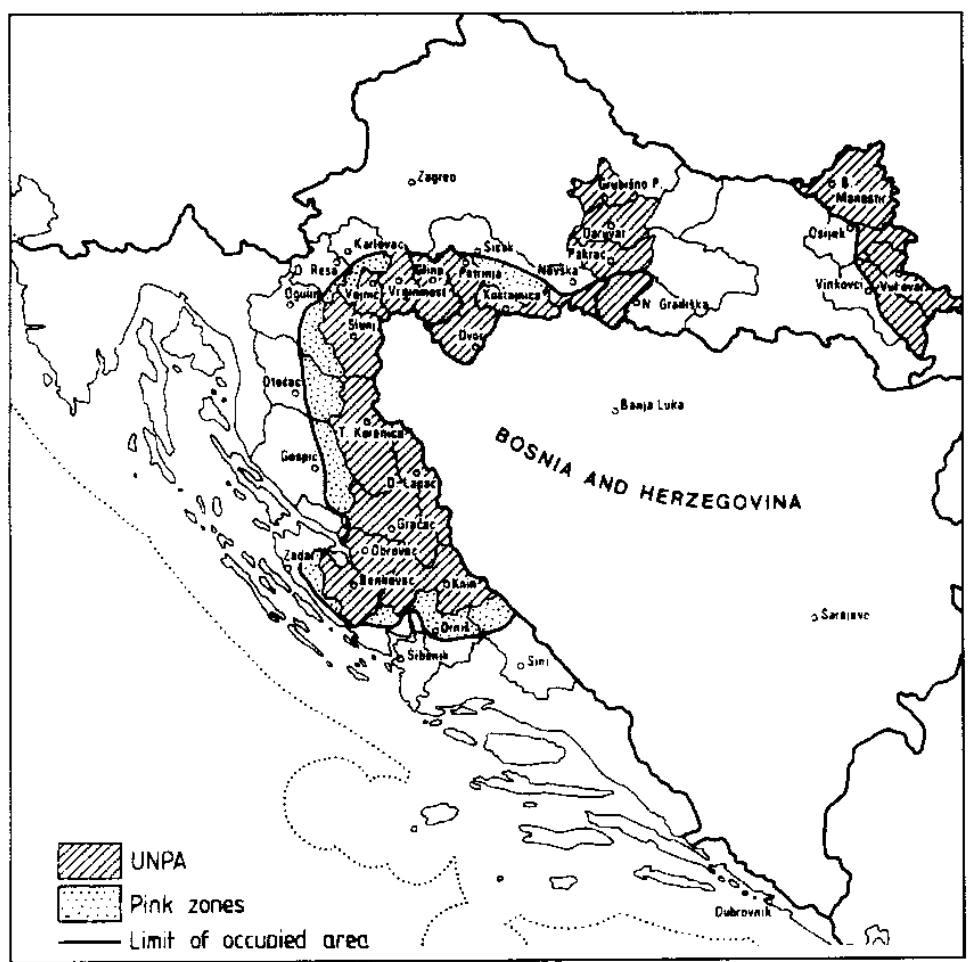

Fig .2. Areas of Croatia directly effected by wartime operations Source: I. Crkvenčić, 1993/94 
Such marked depopulation during the 1961-1991 period was reflected in the corresponding reduction of the overall population density, which at the beginning of the $1990 \mathrm{~s}$ fell to 15.6 inhabitants $/ \mathrm{km}^{2}$. This is approximately 5.4 times below the average in the Republic of Croatia (84.6 inhabitants $/ \mathrm{km}^{2}$ in 1991).

A new, larger reduction in the population of Lika came during the first half of the 1990s, as a result of wartime events during the 1991-1995 events. Because of the heterogeneous national composition (Table 3) and the fact that most of the territory was caught up in wartime operations due to the lateral disjointed disengagement line (zone) (Fig. 2), and the flight of threatened population categories and direct and indirect demographic losses which resulted, Lika belongs among those parts of Croatia with the greatest demographic regression during the $1990 \mathrm{~s}$.

Table 3: National Composition of Lika and its Regions, 1991

\begin{tabular}{|l|c|c|c|c|c|c|c|c|}
\hline & \multicolumn{2}{|c|}{ Total population } & \multicolumn{2}{c|}{ Croats } & \multicolumn{2}{c|}{ Serbs } & \multicolumn{2}{c|}{ Others } \\
\hline Region & Abs. & $\%$ & Abs. & $\%$ & Abs. & $\%$ & Abs. & $\%$ \\
\hline Central Lika* & 28010 & 100 & 17627 & 62.9 & 8955 & 32.0 & 1428 & 29.9 \\
\hline Gacka & 24992 & 100 & 16355 & 65.4 & 7781 & 31.1 & 856 & 30.3 \\
\hline Krbava & 11393 & 100 & 1996 & 17.5 & 8585 & 75.3 & 812 & 36.3 \\
\hline Southern Lika & 10434 & 100 & 1697 & 16.3 & 8371 & 80.2 & 366 & 42.6 \\
\hline Ličko Pounje & 8054 & 100 & 44 & 0.5 & 7854 & 97.5 & 156 & 31.2 \\
\hline LIKA & $\mathbf{8 2 8 8 3}$ & $\mathbf{1 0 0}$ & $\mathbf{3 7 7 1 9}$ & $\mathbf{4 5 . 5}$ & $\mathbf{4 1 5 4 6}$ & $\mathbf{5 0 . 1}$ & $\mathbf{3 6 1 8}$ & $\mathbf{3 2 . 9}$ \\
\hline
\end{tabular}

Source: Population census, 1991. Narodnosni sastav stanovništva Hrvatske po neseljima, Dokumentacija 881, Zagreb, 1992.

During the 1991-1998 period, the population of Lika fell by over 30,000, which represents a rate of 37.2 percent. In accordance with such a demographic regression, the general relative population density fell to below 10 inhabitants $/ \mathrm{km}^{2}$, while in the eastern part of the region the population acquired the features of a true non-ecumene (Table 4).

Table 4: The General Relative Population Density of Lika and its Regions in 1991 and an Estimate of the Population and Population Density in 1998.

\begin{tabular}{|l|c|c|c|c|c|}
\hline Region & $\begin{array}{c}\text { Surface area in } \\
\mathrm{km}^{2}\end{array}$ & $\begin{array}{c}\text { Population, } \\
1991\end{array}$ & inhab./ km & $\begin{array}{c}\text { Est. pop., } \\
1998^{*}\end{array}$ & $\begin{array}{c}\text { inhab./ } \mathrm{km}^{2} \\
1998\end{array}$ \\
\hline & & & & & \\
\hline Central Lika* & 1,393 & 28,010 & 21.1 & 18,356 & 13.2 \\
\hline Gacka & 1,117 & 24,991 & 22.4 & 18,858 & 16.9 \\
\hline Krbava & 1,151 & 11,393 & 9.9 & 7,100 & 6.2 \\
\hline Southern Lika & 1,017 & 10,434 & 10.3 & 5,000 & 4.9 \\
\hline Ličko Pounje & 606 & 8,054 & 13.1 & 2,700 & 4.5 \\
\hline LIKA & $\mathbf{5 , 2 8 4}$ & $\mathbf{8 2 , 8 8 3}$ & $\mathbf{1 5 . 7}$ & $\mathbf{5 2 , 0 1 4}$ & $\mathbf{9 . 8}$ \\
\hline
\end{tabular}

Source: Population census, 1991. *County Statistics Office, Gospić Municipal Council, Gračac (as of: 31 March 1998) 
Such a number and spatial distribution of the population in the region not only hinder the rational spatial organization of this part of highland Croatia, they also represent an increasingly limiting factor for the satisfactory functioning of the national territory as a whole.

\section{Changes in the General Population Trends and Demographic Aging}

The long-term but occasional and very intense emigration of primarily young people and younger age groups of the mature population is above all reflected in the natural trends and accelerated processes of aging of the population.

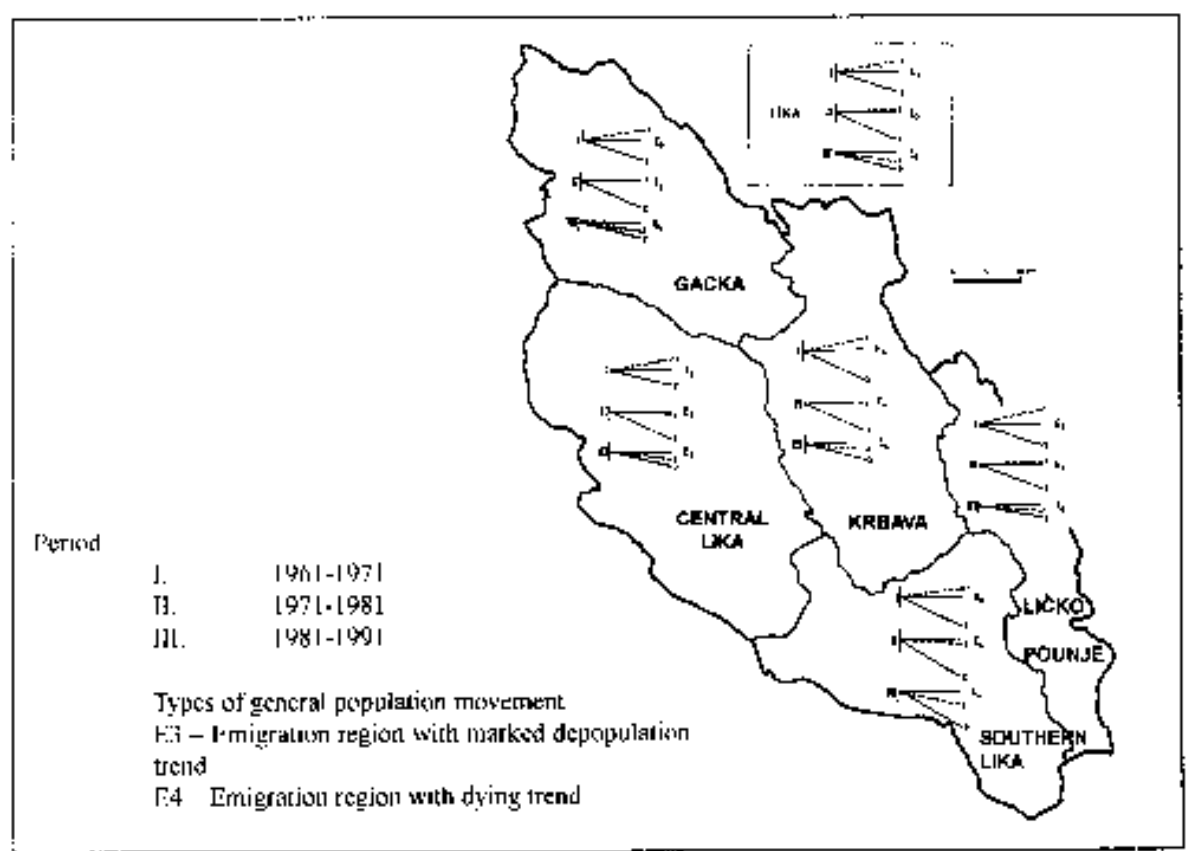

Fig. 3. Types of general population movement in Lika and its regions, 1961 - 1991

The result of this is that the negative natural movement in the region was already recorded during the middle of the 1970s, when the natural decline increased by a geometric progression of $-3,308$, or at a rate of -3.7 percent during the 1981-1991 intercensal period, with its greatest negative value in Central Lika $(-4.1 \%)$.

The negative tendencies of demographic development were already manifested in the general population trends in the 1960s. Thus, during the 1960s and 1970s, the region had the features of an exodus region with a marked depopulation trend, while during the 1980s it was an exodus region with a dying-off trend (Fig. 3). 


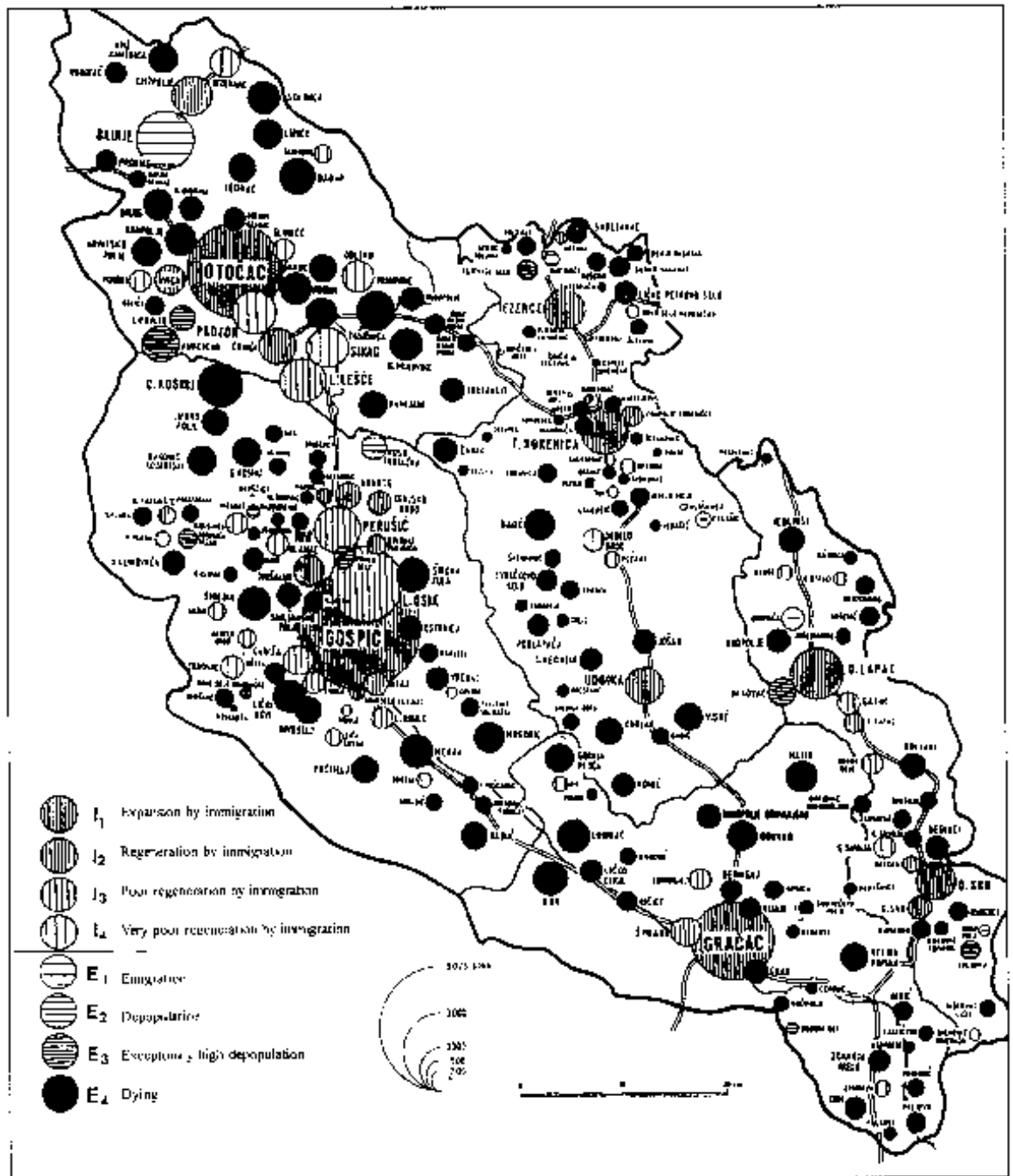

Fig. 4. Types of general population movements in Lika settlements, 1981 - 1991

An analysis of the general population trends in the individual settlements of Lika gives an even more explicit picture of the extent and depth of the process of demographic dying. From this, it can be seen that, with the exception of the few central settlements, almost all of the other settlements are caught in a certain degree of depopulation, while the majority of the minor rural settlements are experiencing a dying trend (Fig. 4). 


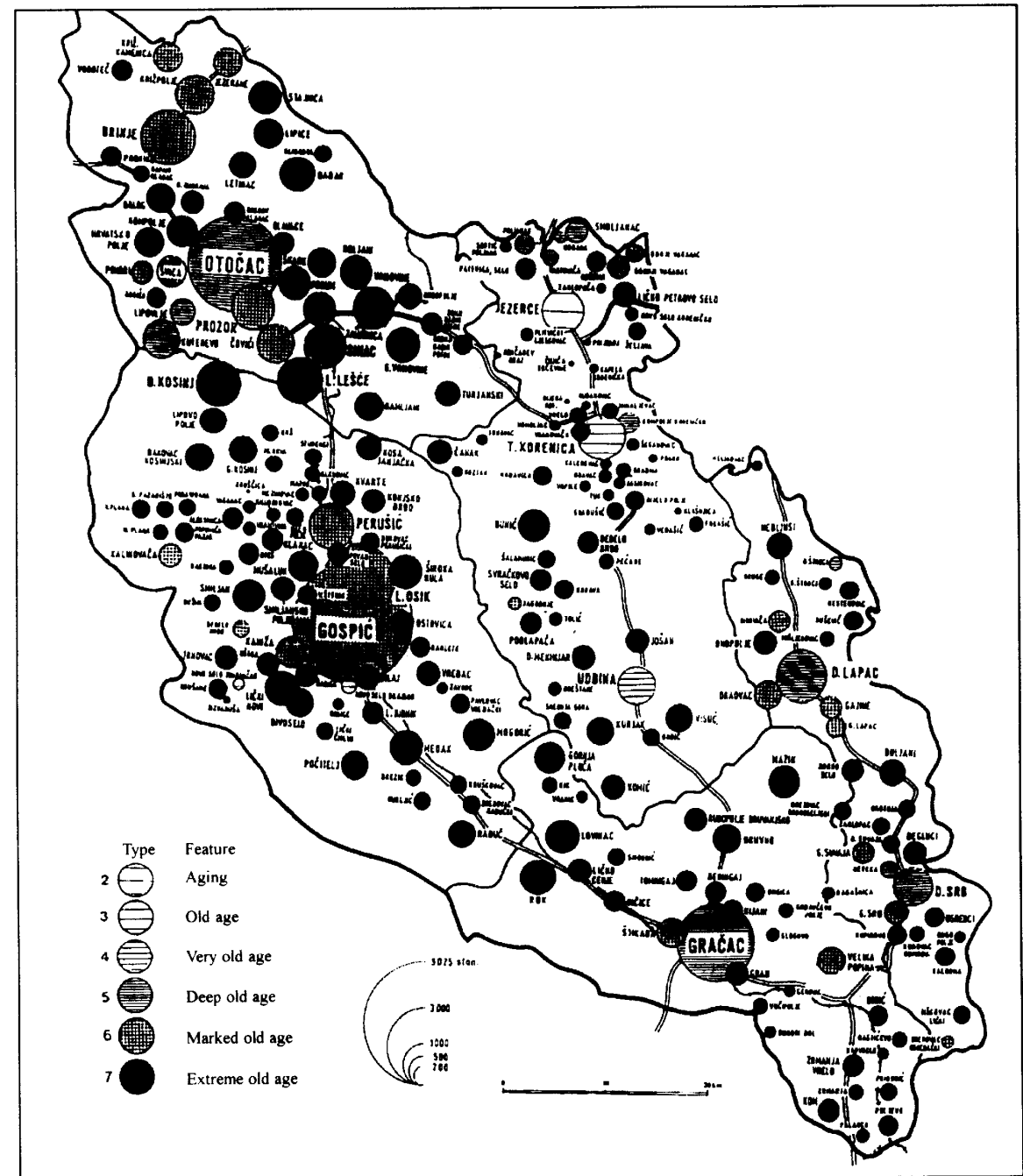

Fig 5. Indicators of population agigng in Lika settlements, 1991

The indicators of the accelerated process of demographic aging are in a direct cause and effect connection with the aforementioned trend of natural decline and the general population trends. At the beginning of the 1990s, as much as 23.4 percent of the population of the region was elderly, which is almost twice the average of Croatia as a whole. Here, the most unfavorable age system could be found in southern Lika, while the least unfavorable was Ličko Pounje. The analysis of the age of the population by settlement (Fig. 5) clearly shows the extent and intensity of the process of aging in the 
region. Here it is important to note that the type of age system termed as "marked old age," actually characterizes even the leading centers of central Lika (Gospić, Lički Osik and Perušić), while the rural settlements can generally be referred to as "extreme old age" type.

\section{Changes in the Agrarian Structure}

Agricultural terrain is one of the most important economic resources of Lika. The region has 299,252 ha of agricultural lands. Their structure, out of which the majority of 240,340 ha or 80.3 percent are meadows and pastures, while 58,912 ha or 10.7 percent are arable surfaces, clearly shows that this region is primarily geared toward cattle rearing and production.

Fast-paced deruralization, depopulation and de-agrarianization, accompanied by accelerated aging processes, i.e. the growth of the share of the population requiring care, have been directly reflected in the reduced use of agricultural lands. The corresponding process of the greening of agricultural lands has been noticeable in the agrarian landscape since the end of the 1960s. By the beginning of the 1980s, the share of uncultivated fields and gardens under individual ownership in many cadastral municipalities, particularly in eastern Lika, grew to over 50 percent (Fig. 6).

Up to 1991, the share of fallow and uncultivated fields in Lika increased to 33.9 percent, which was three times as much as the Croatian average at the time. The range of this phenomena within the region went from 18.4 percent in central Lika to

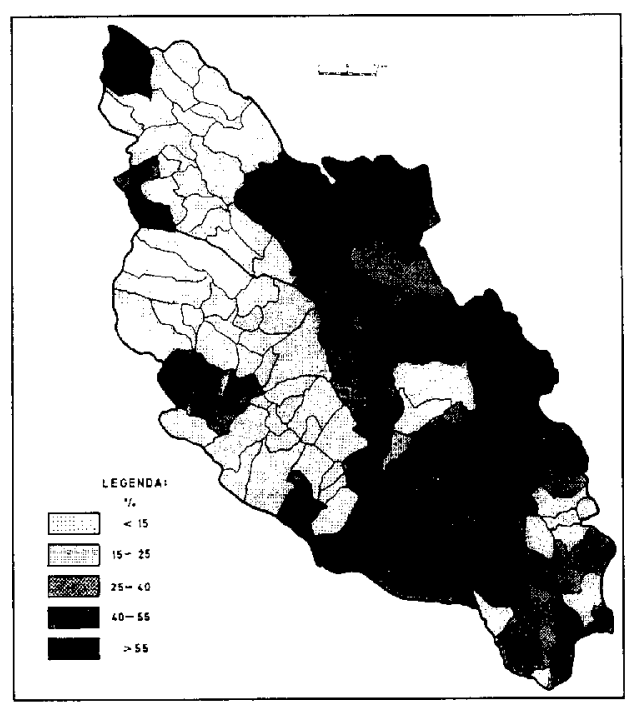

Fig. 6. Share of uncultivated fields and gardens in the total surface area of fields and gardens under private ownership by the cadastral municipalities of Lika in 1980

Source: Municipal Social Planning and Statistics Department, Gospić 67.3 percent in southern Lika.

The war and its consequences have left deep and far-reaching negative effects on the agrarian structure of the region. This is confirmed by data from the Gračac cadastral municipality (southern Lika), where, according to the County Statistics Office in Zadar, in 1996 (one year after military action Operation Storm), the share of fallow 
and uncultivated fields was 96.5 percent. Although the process of resettlement of the population has reduced this share somewhat in the meantime, it is justified to assume that this reduction was insignificant because most of the resettlement has occurred in central settlements. In this sense, data on central Lika from the County Statistics Office in Gospić are more relevant, for according to an estimate for 1998, approximately 40 percent of the arable land went uncultivated or laid fallow. Although there are a number of reasons to take these postwar indicators with a certain reserve, they can as such serve as approximate indicators for the basic direction and intensity of the processes in the agrarian structure of Lika during the 1990s.

\section{Changes in Spatial Organization}

The long-term and increasing stagnation of socio-economic development in Croatia and the ensuing negative changes in demographic dynamics and structures have prevented the formation of hierarchically-organized networks of central settlements in the region. This particularly refers to the slow development of the manufacturing and service industries in Gospić in relation to its potential function as a center of the regional consolidation and integration of Lika. This is confirmed by the fact that in its principal central settlement in 1948 there were 4,204 inhabitants, while in 1991, i.e. after over forty years, the population only grew to 9,025 inhabitants.

Since Gospić did not develop into a center of greater centrality in relation to the subregional centers (Otočac, 5,404; Gračac, 4,101; Korenica, 1,716; Donji Lapac, 1,971; populations according to 1991 census) because of the region's slow development, this has actually made Lika a functionally disintegrated area. The transit-corridor network of roads conditioned by the relief has contributed to this considerably. This road network has not conditioned concentration nor the formation of hubs which would lead to greater regional consolidation. This has had a causative effect in the incongruity between the nominal organization within the framework of the Rijeka functional macro-region and the actual greater gravitational orientation toward Zagreb (Fig. 7).

This inconsistent spatial organization, with an undeveloped network of central settlements and its non-articulation as a nodal-functional system, as well as the transportation and geographic disunity, is one of the most important factors in the complex cause and effect problem of emigration and the process of negative sociogeographic differentiation in Lika which results from it. 


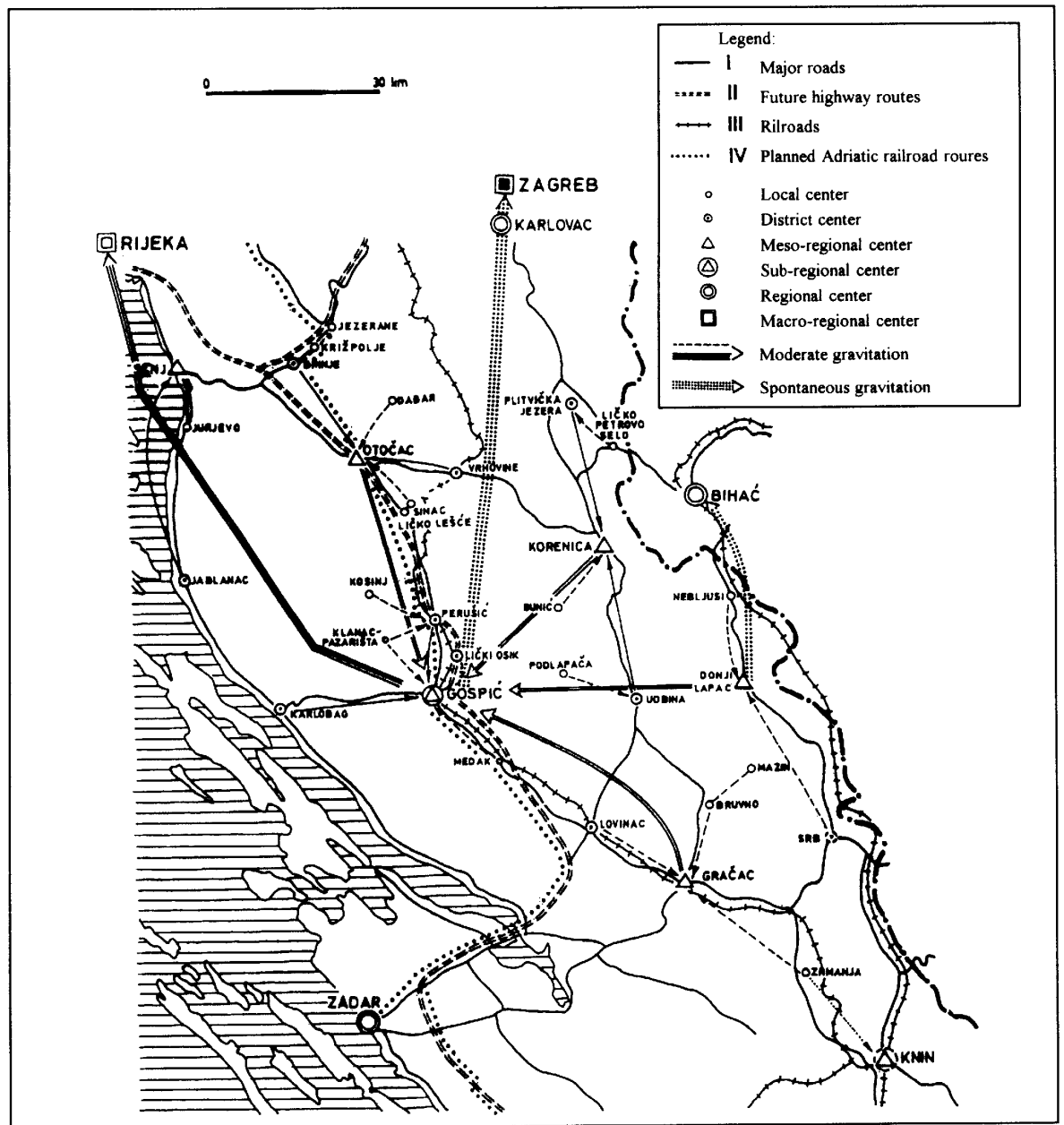

Fig. 7. Nodal-functional organisation of Lika up to the beginning of the 1990s

\section{CONCLUSION AND PERSPECTIVES}

According to the actual indicators of the demographic, economic and social development, Lika is the greatest problem region in the Republic of Croatia. The crisis features of its contemporary development are directly reflected in the largely devastated socio-geographic structure. Its development is becoming an increasing obstacle to the successful spatial-functional integration of the state as a whole. 
A majority of the territory, the importance of the regional-geographic position and the autochthonous economic potential that determine the significance of the region to national development, demand that decisive measures be undertaken for the revitalization of this part of highland Croatia. This revitalization is certainly very closely tied with the policy of more coordinated regional development within the Republic of Croatia.

Using the causes of Lika's development into the leading Croatian problem region as a starting point, there are three spatial-planning measures that have a key significance to its revitalization:

1. immigration policy (return of the local population and the attraction of younger and better educated people from urban centers);

2. multi-sector economic development (with an orientation toward profitable activities in the function of stimulating immigration);

3. consistent spatial organization (based on a regular nodal-functional hierarchy with Gospić as the developmental-gravitational focus and the corresponding transit system in order to facilitate more effective ties between Lika and Rijeka as the center of its functional macro-region).

Here it is essential to take into account the function of this part of highland Croatia as the environmental heart of the country, which implies the planning of its development as a protected area.

The aforementioned measures were basically adopted in the draft Spatial Planning Program of the Republic of Croatia for 1998. Thus, the revitalization of Lika-as Croatia's greatest problem region-will depend on the perseverance and consistency of this program's implementation in this exceptionally vital part of the national territory.

\section{REFERENCES AND SOURCES}

1. Bićanić R., 1940: Agrarna prenapučenost. Gospodarska sloga, Zagreb.

2. Bićanić R., 1974-75: Ekonomska podloga događaja 1903. g. u Hrvatskoj. Historijski zbornik, god. 23-24, Zagreb.

3. Crkvenčić I., 1993/94: Areas of Aggression in Croatia (Basic Historical and Demographic Facts). Croatia-A New Europpean State, Zagreb.

4. Figenwald V., 1964: Viškovi poljoprivrednog stanovništva u SR Hrvatskojanalitička ocjena. Prikazi, 17, Republički zavod za statistiku SR Hrvatske, Zagreb. 
5. Horvat V., 1942: Suvremene nutarnje seobe i kretanja Hrvata-posljedica dinamike društvenih procesa. Hrvatska državna tiskara, Zagreb.

6. Lakatoš J., 1914: Narodna statistika, Zagreb.

7. Maticka M., 1990: Agrarna reforma i kolonizacija u Hrvatskoj 1945.-1948. Povijesna istraživanja, Školska knjiga - Stvarnost, Zagreb.

8. Mikačić V., 1978: Regionalni aspekt poslijeratnog iseljavanja iz Hrvatske u prekomorske zemlje, teme o iseljeništvu, sv. 8. Centar za istraživanje migracija, Zagreb.

9. Narodne novine, $18 / 1966,33 / 1976$.

10. Nejašmić I., 1991: Depopulacija u Hrvatskoj, Korijeni, stanje, izgledi. Globus nakladni zavod, Institut za migracije i narodnosti Sveučilišta u Zagrebu, Zagreb.

11. Pejnović D., 1991: Opće kretanje stanovništva kao odraz i pokazatelj socijalnogeografske diferencijacije Like. Radovi, 26, Geografski odjel PMF-a, Zagreb.

12. Pejnović D., 1996: Geografski aspekt revitalizacije depopulacijskih i ratom pogođenih područja Hrvatske na primjeru Like. Zbornik I. hrvatskog geografskog kongresa, Zagreb.

13. Pejnović D., 1997: Geopolitički položaj Krbave u srednjovjekovnom, osmanlijskom i vojnokrajiškom razdoblju. U zborniku: Krbavska bitka i njezine posljedice, Hrvatska matica iseljenika, Zagreb.

14. Popis stanovništva 1991, Narodnosni sastav stanovništva Hrvatske po naseljima. Dokumentacija 881, Zagreb, 1992.

15. Program prostornog uređenja Republike Hrvatske, prijedlog. Zagreb, 1998.

16. Razvoj privredno nedovoljno razvijenih krajeva SR Hrvatske. Ekonomski institut, Zagreb, 1985. (uredio: Z. Baletić)

17. Roksandić D., 1985: Iz ranije prošlosti kotara Donji Lapac. U zborniku: Kotar Donji Lapac u NOR-u 1941-1945, Historijski arhiv u Karlovcu, zbornik 14, Karlovac.

18. Žerjavić V., 1989: Gubici stanovništva Jugoslavije u drugom svjetskom ratu. Jugoslavensko viktimološko društvo, Zagreb.

19. Županijski ured za statistiku, Gospić, 1998.

20. Županijski ured za statistiku, Zadar, 1998. 


\title{
LIKA - PRIMJER SOCIJALNOGEOGRAFSKE TRANSFORMACIJE GORSKE HRVATSKE
}

\begin{abstract}
Sažetak
Geografski pojam Like odnosi se na prostranu kršku zavalu u jugoistočnom dijelu gorske Hrvatske, između planinskih nizova Velebita, Kapele i Plješevice, odnosno rijeke Une.

Kao krški prostor s rubnim socijalno-geografskim položajem, to je jedno od klasičnih emigracijskih područja Hrvatske koje karakterizira dugotrajno a povremeno i veoma intenzivno iseljavanje. Do najvećeg iseljavanja u novije vrijeme došlo je od početka šezdesetih godina, kada je zbog njezina zaostajanja u društveno-gospodarskom razvoju Hrvatske iz Like emigrirala oko trećina njezina stanovništva.

Tako izrazita socijalna i prostorna pokretljivost izvan Regije, s obilježjima ruralnog egzodusa, ostavila je duboke, negativne tragove u demografskom, gospodarskom i socijalno-geografskom razvoju Like. Njezin rezultat su obilježja egzodusnog prostora $\mathrm{s}$ trendom izrazite depopulacije tijekom šezdesetih, negativno prirodno kretanje stanovništva od početka sedamdesetih te krajnje duboka starost stanovništva i opće kretanje stanovništva s trendom izumiranja u osamdesetim godinama.

To se posljedično odrazilo u još većem zaostajanju u društveno-gospodarskom razvoju Hrvatske, naglom porastu udjela neobrađenih obradivih površina i atrofiji mreže naselja, bez mogućnosti oblikovanja hijerarhijski oblikovanog nodalnofunkcionalnog sustava. Prethodno začeti negativni procesi do krajnosti su intenzivirani posljedicama rata 1991.-1995. što se sveukupno očituje u postojećem visokom stupnju devastacije socijalno-geografske strukture ovog prostora.

Aktualna nastojanja za revitalizacijom tog najvećeg problemskog područja Hrvatske najuže su povezana s politikom usklađenijeg regionalnog razvoja unutar države. Pritom među razvojnim mjerama na razini Regije posebno značenje imaju imigracijska populacijska politika, multisektorski gospodarski razvoj i konzistentna prostorno-funkcionalnu organizaciju.
\end{abstract}




\section{DISCRIPTION OF FIGURES AND THEIR LEGENDS:}

Fig. 1. Regional and geographic position of Lika

Legend:

A) Physiognomic homogenous regionalization

1. Western Pannonian area

1.1. Northwestern Croatia

1.2. Northwestern Bosnia

2. Dinaric mountain area

2.1. Highland Croatia

2.1.1. Gorski Kotar

2.1.2. Ogulin-Plaški depression

2.1.3. Lika

2.2. High karst of Bosnia-Herzegovina

3. Adriatic-Mediterranean area

3.1. Northern Croatian littoral

3.2. Southern Croatia

B) Nodal-functional organization

- Macro-regional center

- Regional center

- Sub-regional center

Basic direction of primary transit tension

Basic direction of secondary transit tension

State border

Border of functional macro-region

(Zagreb, Rijeka, Split)

Fig. 2. Areas of Croatia directly effected by wartime operations

Fig. 3. Types of general population movement in Lika and its regions, 1961-1991

Period

I. 1961-1971

II. 1971-1981

III. 1981-1991

Types of general population movement E3 - Emigration region with marked depopulation trend

E4 - Emigration region with dying trend 
Fig. 4. Types of general population movement in Lika settlements, 1981-1991

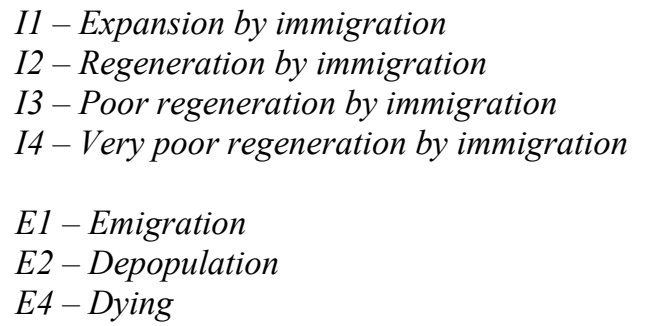

Fig. 5. Indicators of population aging in Lika settlements, 1991

Type

Feature

2. - Aging

3. - Old age

4. - Very old age

5. - Deep old age

6. - Marked old age

7. - Extreme old age

Fig. 6. Share of uncultivated fields and gardens in the total surface area of fields and gardens under private ownership by the cadastral municipalities of Lika in 1980 (Source: Municipal Social Planning and Statistics Department, Gospić)

Fig. 7. Nodal-functional organization of Lika up to the beginning of the 1990s Legend:

- Local center

- District center

- Meso-regional center

- Sub-regional center

- Regional center

- Macro-regional center

Moderate gravitation

Spontaneous gravitation 